\title{
Pharmacotherapy in the Cardiac Catheterization Laboratory
}

\section{Chiara Bernelli*}

Interventional Cardiology Unit, Azienda Ospedaliera Papa Giovanni XXIII, Bergamo, Italy

\begin{abstract}
Cardiovascular pharmacology and therapeutics have been subject to an enormous amount of change and evolution during the last years in parallel with the revolutions in the field of catheterization laboratory. Advances in adjunct pharmacotherapy have been the foundation for progress in the catheterization laboratory. Indeed, pharmacotherapy remains essential in preventing potential complications during both diagnostic and interventional procedures and in optimizing the mechanical reperfusion therapy. Furthermore, the interventionalist must be prepared and able to medically manage an unparalleled range of conditions, ranging from diabetes and chronic kidney disease to complications such as hypotension, arrhythmias, and anaphylaxis which may present in the catheterization laboratory. The present review focuses on the appropriate utilization of adjunct pharmacotherapy in the catheterization laboratory with respect to their actions, prescribed usage, dosages, adverse reactions, cautions and common routes of administration.
\end{abstract}

Keywords: Cath lab; Pharmacotherapy; Contrast-induced acute kidney injury

\section{Introduction}

Alongside all devices available in the catheterization laboratory, adjunctive pharmacotherapy remains essential to optimize diagnostic and treatment strategies during both diagnostic and interventional procedures. Pharmacotherapy may indeed prevent potential complications especially in patients at high risk, beside to help the physicians in managing emergency clinical scenarios. The armamentarium of drugs offered to the interventional cardiologists and to the Cath Lab team is really wide. The following review is aimed to illustrate the potential applications of pharmacotherapy in Cath Lab during diagnostic and interventional procedures.

\section{Basic Pharmacology for Diagnostic/Interventional Procedures in Cath Lab}

\section{Prevention of contrast-induced acute kidney injury}

An issue to consider in patients undergoing diagnostic and interventional procedures is the prevention of Contrast-induced Acute Kidney Injury (CI-AKI) due to the use of contrast media. Patients have varying risks for the development of CI-AKI and efforts to risk stratify patients should be performed [1]. Factors associated with higher incidence ofCI-AKI were a low estimated glomerular filtration rate (GFR $<60 \mathrm{~mL} / \mathrm{min}$ per $1.73 \mathrm{~m}^{2}$ ), diabetes mellitus and contrast media dose. Further, dehydration secondary to inadequate fluid intake or diuretic agents potentiates the risk. Thus, adequate hydration and withdrawal of any potentially nephrotoxic medications should be performed prior to the procedure. Several drugs were assessed to prevent CI-AKI such as calcium antagonists, adenosine antagonists, N-acetylcysteine, prostaglandin analogs, L-arginine, statins, atrial natriuretic peptide, endothelin antagonists, dopamine, fenoldopam, hypertonic mannitol, and furosemide [1]. However, with the possible exception of high-dose $\mathrm{N}$-acetylcysteine, no treatment has been unequivocally proven efficient in reducing CI-AKI risk, while endothelin antagonists may even have detrimental effects. Conversely, isotonic saline and bicarbonate-based hydration have been demonstrated to reduce the rate of CI-AKI. A common hydration protocol employed by several Cath Labs to prevent CI-AKI consists in the intravenous (IV) administration of 1.0-1.5 ml/ $\mathrm{kg} / \mathrm{h}$ of isotonic saline for 3-12 hours before and up to 6-12 hours after contrast media exposure. For example: for a $60 \mathrm{~kg}$ patient, without signs of congestion, $60-90 \mathrm{ml} /$ hour should be administered for 3-12 hours prior to the procedure and up to 6-12 hours after the procedure. In patients with congestions this dose should be halved. According to the recent randomized POSEIDON trial, a hydration protocol based on measured haemodynamic demonstrated to improve clinical outcomes for up to 6 months. Hydration with normal saline personalized on the basis of left ventricular end-diastolic pressure resulted in a significantly lower rate of death, myocardial infarction (MI), or dialysis at that time point compared with standard hydration (3.1\% versus $9.5 \%$; RR $0.32,95 \%$ CI 0.13 to 0.79 ) [2]. The use of a bicarbonate-based hydration $\left(\mathrm{NaHCO}_{3} 3 \mathrm{ml} / \mathrm{kg} / \mathrm{h}\right.$ for $1 \mathrm{~h}$ before and $1 \mathrm{ml} / \mathrm{kg} / \mathrm{h}$ for $6 \mathrm{~h}$ after procedure) in comparison to normal saline also demonstrated to significantly reduce the incidence of CI-AKI. The use of sodium bicarbonate, however, did not result in significant benefit in terms of a reduction in deaths or the requirement for dialysis [3]. A general protocol to prevent CI-AKI is illustrated in Table 1.

Premedication for patients at high risk for anaphylactoid reaction to contrast media

Steroids and histaminic receptor 1 antagonists (H1 blockers) are the basic components of most premedication regimens for patients at high risk for an anaphylactoid reaction to contrast media. Prednisone $50 \mathrm{mg}$ per os (p.o.) should be administered 13, 7 and 1 hour before procedure together with diphenhydramine $50 \mathrm{mg}$ p.o. $1 \mathrm{hr}$ before procedure. This is effective in the reduction of recurrent anaphylactoid reactions to standard contrast agents [4].

\section{Conscious sedation during cardiac catheterization procedures}

Some Cath Labs, especially in the Unites States, administer

*Corresponding author: Chiara Bernelli, MD, Interventional Cardiology Unit Ospedale Papa Giovanni XXIII Piazza OMS, 124127 Bergamo, Italy, Tel: +39 035 2673452; Fax: +39 035 400491; E-mail: chiarabernelli@yahoo.it

Received April 20, 2015; Accepted June 04, 2015; Published June 10, 2015

Citation: Bernelli C (2015) Pharmacotherapy in the Cardiac Catheterization Laboratory. Cardiol Pharmacol 4: 146. doi:10.4172/2329-6607.1000146

Copyright: (c) 2015 Bernelli C. This is an open-access article distributed under the terms of the Creative Commons Attribution License, which permits unrestricted use, distribution, and reproduction in any medium, provided the original author and source are credited. 
- High risk patients with eGFR $>60 \mathrm{ml} / \mathrm{min} / 1.73 \mathrm{~m}^{2}$ (i.e. diabetics): Intravenous volume expansion with $1 \mathrm{ml} / \mathrm{kg}$ bodyweight $/ \mathrm{hr}$ of $0.9 \%$ saline $3-12 \mathrm{hours}$ before and up to 6-12 hours post procedure. In patients with signs of congestions or elevated left ventricular end-diastolic pressure this dose should be halved.

- If eGFR $<60 \mathrm{ml} / \mathrm{min} / 1.73 \mathrm{~m}^{2}$ : Intravenous volume expansion- $1 \mathrm{ml} / \mathrm{kg}$ bodyweight $/ \mathrm{hr} 0.9 \%$ saline $3-12$ hours before and up to $6-12$ hours post procedure. If possible limit contrast volume. In patients with signs of congestions or elevated left ventricular end-diastolic pressure this dose should be halved.

- If eGFR $<30 \mathrm{ml} / \mathrm{min} / 1.73 \mathrm{~m}^{2}$ : Intravenous volume expansion- $1 \mathrm{ml} / \mathrm{kg}$ bodyweight $/ \mathrm{hr} 0.9 \%$ saline $3-12$ hours before and up to $6-12$ hours post procedure. In patients with signs of congestions or elevated left ventricular end-diastolic pressure this dose should be halved. Limit contrast volume. Administer NaHCO 3 $\mathrm{ml} / \mathrm{kg} / \mathrm{h}$ for $1 \mathrm{~h}$ before and $1 \mathrm{ml} / \mathrm{kg} / \mathrm{h}$ for $6 \mathrm{~h}$ after procedure or $\mathrm{N}$-acetylcysteine-1200 $\mathrm{mg}$ twice daily day before and day of procedure.

eGFR indicates estimated Glomerular Filtration Rate by MDRD formula

Table 1: Protocol to prevent contrast-induced acute kidney injury in cath lab.

routinely pre-procedural intravenously benzodiazepines [diazepam (5 $\mathrm{mg}$ ) or midazolam (1 mg)] or diphenhydramine $(25 \mathrm{mg})$ to obtain a conscious sedation of the patients [5]. However, patient sedation may be preferred if the patient is agitated or highly anxious. Morphine $2 \mathrm{mg}$, an opioid, can be also administered. Flumazenil is a pure benzodiazepine antagonist and can be used for reversal of benzodiazepine sedation in case of benzodiazepine overdose (dosage $0.2 \mathrm{mg}$ IV over $15-30 \mathrm{sec}$ ). It has a shorter duration of action than the benzodiazepine agents it reverses. Therefore, further doses may be given at 60 second intervals if required. In case of morphine has been used, the most serious problem is respiratory depression that may require reversal of sedation. Naloxone, a competitive antagonist of the opioid receptors, is used for reversal of narcotic analgesics (morphine) at dosage of $0.001 \mathrm{mg} / \mathrm{kg} \mathrm{IV}$.

\section{Local anesthetics}

Adequate local anesthesia is essential for a successful catheterization. Inadequate anesthesia leads indeed to poor patient ooperation and makes the time in the Cath Lab unpleasant for both patient and operator. The most used local anesthetics in Cath Lab is lidocaine $1 \%$ or $2 \%$ ( $\mathrm{fl} 10 \mathrm{ml}$ ) in dosage of $10 \mathrm{ml}$ to get femoral access or $2 \mathrm{ml}$ in case of radial/ulnar access. To reduce the burning reactions during radial access some Labs administer $2 \mathrm{ml}$ of lidocaine plus $1 \mathrm{ml}$ of $\mathrm{NaHCO}_{3}$. The incidence of allergy to lidocaine is less than $1 \%$. In such cases mepivacaine $1 \%$ and bupivacaine $0.25 \%$ of concentration should be used.

\section{Agents to Optimize Radial Artery Approach}

During the puncture or procedures on the radial artery, a variety of stimuli may result in artery spasm. Prophylactic use of pharmaceutical agents known to reduce radial vascular tone, such as calcium channel blockers (e.g., Verapamil $2.5 \mathrm{mg}$ ) and/or nitrates (e.g., Nitroglycerin 0.1-0.4 mg) are routinely utilized and are best given directly in the radial artery immediately after vascular access. An example of a radial cocktail administered is formed by $2 \mathrm{mg}$ of Verapamil $(0.8 \mathrm{ml}$ of a 5 $\mathrm{mg}$ in $2 \mathrm{ml}$ preparation), $200 \mathrm{mcg}$ of nitrate, $1 \mathrm{ml}$ of $1 \%$ lidocaine and $1 \mathrm{ml}$ of bicarbonate. In addition, diluting the spasmolytic cocktail with blood or saline can reduce burning and artery irritation [6]. Particular caution in using spasmolytic cocktail should be used in patients prone to hypotension related to these agents, such as those with severe aortic stenosis. Although there is no strong evidence demonstrating superiority of any one pharmacologic regimen, it has been demonstrated that lack of pretreatment is associated with symptomatic spasm in up to $30 \%$ of cases [7]. A $2500-5000$ international units (IU) of unfractionated heparin (UFH) are also usually given even during diagnostic procedures (dose, timing and route of administration determined by operator) to reduce the risk of radial occlusion.

\section{Coronary vasodilators (Nitrates)}

Nitroglycerin is a nitric oxide (NO) donor that acts as coronary arterial vasodilator and venodilator, dilatating normal and stenotic vessels. Intracoronary (IC) administration of nitrate $(100-250 \mathrm{mcg})$ should be routinely administered during coronary angiography prior to cine acquisition [8]. A dosage of $10-50 \mathrm{mcg}$ is associated with a selective coronary vasodilation, with an IC dosage of 100-200 mcg there is a mild systemic hypotension and for dosages $>250 \mathrm{mcg}$ there is an increased risk of hypotension without coronary flow augmentation. Of note, spontaneous coronary artery spasm is diagnosed as the relief of obstructive stenosis after IC nitroglycerin administration, emphasizing the importance of this drug in clinical decision making.

\section{Coronary vasoconstrictors}

Provocative testing with the use of coronary vasoconstrictors usually is required to establish a definitive diagnosis of coronary reactivity and coronary artery spasm [9]. Ergonovine and acetylcholine are the most commonly used agents for provocative testing. Ergonovine in IC doses of 1,5 to $10 \mu \mathrm{g}$ produces vasoconstriction acting on smooth muscle mainly via activation of serotonergic (5-HT2) receptors. Only methylergonovine is currently available in the United States. Adverse reactions to ergot alkaloids include angina, ischemia, MI, arrhythmia, nausea, allergic reaction, and ergotism. Acetylcholine in IC doses of 10 to $100 \mu \mathrm{g}$ acts on the endothelium and smooth muscle via muscarinic receptors. In healthy endothelium, acetylcholine activation results in vasodilation. However, in the setting of endothelial dysfunction acetylcholine causes vessel contraction rather than vasodilation. Adverse reactions to acetylcholine include hypotension, bradycardia, dyspnea, and flushing. Atropine is used to suppress acetylcholineinduced coronary artery spasm.

\section{Anticholinergics for vagal reactions}

A vasovagal reaction is a sudden drop in blood pressure, heart rate and cardiac output. It is the result of the stimulation of the parasympathetic nervous systems and its physical responses are manifested by activation of the vagus nerve. In the Cath Lab, a vagal reaction can occur with the mere sight of a needle, but more commonly is triggered by pain [10]. Treatment for vasovagal reaction consists in the atropine use that blocks vagal stimulation, slows the heart rate and contrasts hypotension. Doses of $1.0 \mathrm{mg}$ IV can be given immediately and reverse bradycardia and hypotension within 2 minutes. Vasoconstrictors such as phenylephrine $(0.2 \mathrm{mg})$ or ephedrine (5-25 $\mathrm{mg}$ IV) are reserved for persistent hypotension after recovery of heart rate.

\section{Pulmonary vasoreactivity test during right heart catheterization}

The measurement of pulmonary vasoreactivity has an extremely important role in the diagnosis and management of patients with pulmonary arterial hypertension (PAH) beside to provide a prognostic role [11]. Patients with $\mathrm{PAH}$ who lack pulmonary vasoreactivity must be treated with specific pulmonary vasodilators. Patients with significant pulmonary vasoreactivity, by contrast, have been shown to respond well to calcium channel blockers therapy. Table 2 illustrates the indications to pulmonary vasoreactivity test during right heart catheterization and dosage of the 3 agents currently used 
for pulmonary vasoreactivity testing. The test is considerate positive when there is a $20 \%$ drop of pulmonary vascular resistance, a decrease in mean pulmonary arterial pressure of at least $10 \mathrm{~mm} \mathrm{Hg}$ with the mean pulmonary arterial pressure decreasing to $40 \mathrm{~mm} \mathrm{Hg}$ or less, accompanied by a normal or high cardiac output.

\section{Pharmacology for Ischemic Heart Disease in Cath Lab}

Many recent innovations have been made in developing new antiplatelet and anticoagulant drugs in the last few years, revolutionizing the antithrombotic therapy given to support percutaneous coronary intervention (PCI) and to manage acute coronary syndrome (ACS). Antiplatelets and anticoagulants, that act in two crucial points of hemostasis (platelet reactivity and the coagulation cascade), remain crucial in the management of ACS as well as in assisting PCI in stable coronary artery disease (CAD). The choice, initiation, combination, and duration of antithrombotic strategies for myocardial revascularization depend on the clinical setting: stable CAD, Non STelevation Myocardial Infarction (NSTEMI), ST-elevation Myocardial Infarction (STEMI), and the urgency of the intervention.

\section{Antithrombotic Therapy in Stable CAD after PCI}

Antithrombotic regimen after PCI in patients with stable CAD is summarized in Figure 1 [12]. Dual antiplatelet therapy (DAPT) in stable CAD after PCI includes a $150-300 \mathrm{mg}$ oral loading dose of acetylsalicylic acid (ASA) (or $80-150 \mathrm{mg}$ IV) followed by 75$100 \mathrm{mg}$ per o.s. daily plus a clopidogrel $300-600 \mathrm{mg}$ loading dose

\section{Indications}

- $\quad$ Cases of idiopathic PAH or cases of PAH associated with systemic diseases with in order to evaluate treatment options

- $\quad$ Cases of candidates for heart transplantation

- Cases of complicated congenital heart disease and severe PAH in which clinical and noninvasive tests are inconclusive as to the best approach Drugs

- IV adenosine infusion: 6-12 mg IV in 3-5 minutes

- IV prostacyclin infusion 2-10 $\mathrm{ng} / \mathrm{kg}$ in 2 minutes

- Inhaled nitric oxide: 20-40 ppm 3-5 minutes

$\mathrm{PAH}=$ pulmonary artery hypertention is defined as a pulmonary artery pressure $>25 \mathrm{mmHg}$ evaluated invasively through right heart catheterization; IV=intravenous ppm=part per million

Table 2: Pulmonary vasoreactivity test during right heart catheterization: indications and drugs.

\begin{tabular}{|c|c|c|}
\hline Recommendations for PCI & Class $^{2}$ & Level $^{2}$ \\
\hline \multicolumn{3}{|l|}{ Pretreatment with antiplatelet therapy } \\
\hline $\begin{array}{l}\text { Treatment with } 600 \mathrm{mg} \text { clopidogrel is recommended in elective } \mathrm{PCl} \text { patients once anatomy is known and decision to } \\
\text { proceed with } \mathrm{PCl} \text { preferably } 2 \text { hours or more before the procedure. }\end{array}$ & $\mathbf{I}$ & A \\
\hline Pretreatment with clopidogrel may be considered in patients with high probability for significant CAD. & Illb & c \\
\hline $\begin{array}{l}\text { In patients on a mainternance dose of } 75 \mathrm{mg} \text { clopidogrel, a new loading dose of } 600 \mathrm{mg} \text { or more may be considered } \\
\text { once the indication for } \mathrm{PCl} \text { is confirmed. }\end{array}$ & Illb & c \\
\hline \multicolumn{3}{|l|}{ Antiplatelet therapy during $\mathrm{PCl}$} \\
\hline ASA is indicated before elective stenting. & 1 & B \\
\hline ASA oral loading dose of $150-300 \mathrm{mg}$ (or $80-150 \mathrm{mg}$ i.v.) is recommended if not pre-treated. & 1 & c \\
\hline Clopidogrel ( $600 \mathrm{mg}$ loading dose or more, $75 \mathrm{mg}$ daily maintenance dose) is recommended for elective stenting. & 1 & $\mathbf{A}$ \\
\hline GP Ilb/llla antagonists should be considered only for bail-out. & Ila & c \\
\hline \multicolumn{3}{|l|}{ Antiplatelet therapy after stenting } \\
\hline DAPT is indicated for at least 1 month after BMS implantation. & 1 & A \\
\hline DAPT is indicated for 6 months after DES implantation. & 1 & B \\
\hline Shorter DAPT duration ( $<6$ months) may be considered after DES implantation in patients at high bleeding risk. & Illb & A \\
\hline Life-long single antiplatelet therapy, usually ASA, is recommended. & $\mathbf{I}$ & A \\
\hline Instruction of patients about the importance of complying with antiphtelet therapy is recommended. & 1 & c \\
\hline DAPT may be used for more than 6 months in patients at high ischaemic risk and low bleeding risk. & Illb & C \\
\hline \multicolumn{3}{|l|}{ Anticoagulant therapy } \\
\hline Unfractionated heparin 70-100 U/kg. & 1 & B \\
\hline $\begin{array}{l}\text { Bivalirudin ( } 0.75 \mathrm{mg} / \mathrm{kg} \text { bolus, followed by } 1.75 \mathrm{mg} / \mathrm{kg} / \mathrm{hour} \text { for up to } 4 \text { hours after the procedure) in case of } \\
\text { heparin-induced thrombocytopenin. }\end{array}$ & $\mathbf{I}$ & C \\
\hline Bivalirudin ( $0.75 \mathrm{mg} / \mathrm{kg}$ bolus, followed by $1.75 \mathrm{mg} / \mathrm{kg} / \mathrm{hour}$ during the procedure) in patients at high bleeding risk. & Illa & A \\
\hline Enoxaparin i.v. $0.5 \mathrm{mg} / \mathrm{kg}$. & Illa & B \\
\hline
\end{tabular}

Figure 1: Antithrombotic treatment in patients with stable CAD undergoing $\mathrm{PCI}$. 
followed by $75 \mathrm{mg}$ daily. A loading dose of $600 \mathrm{mg}$ is recommended in patients scheduled for elective PCI if coronary anatomy is known. Acetylsalicylic acid acts inactivating prostaglandin $\mathrm{G} / \mathrm{H}$ synthase via irreversible inhibition of platelet cyclo-oxygenase-1 (COX-1), the first step in the conversion of arachidonic acid to thromboxane A2. Clopidogrel, a thienopyridine, is a prodrug that is converted in active metabolites through a two-step reaction involving cytochrome P450 (CYP450) enzymes, leading to an irreversible blockade of the platelet P2Y12 receptor. Anticoagulation with UFH with an IV bolus of 70-100 $\mathrm{U} / \mathrm{kg}$ remains the standard anticoagulant treatment for elective PCI. Bivalirudin might be considered for use in patients at high risk for bleeding. When compared with UFH, intravenous enoxaparin $(0.5 \mathrm{mg} /$ $\mathrm{kg}$; or $0.75 \mathrm{mg} / \mathrm{kg}$ ) was associated with less major bleeding with both doses, with similar efficacy to UFH.

\section{Pharmacotherapy in Acute Coronary Syndromes}

The objectives of pharmacotherapy in the acute phase of ACS can be reassumed as the following: 1) reduce thrombotic burden, 2) enhance vessel patency and myocardial tissue perfusion, 3) obtain an immediate symptoms control, 4) reduce risk of recurrent thrombosis and 6) minimize bleeding complications. Tables 3 and 4 reassume the management and the therapeutic strategies in ACS [12].

Routine Medical Therapy in ACS: Although nitroglycerin can ameliorate symptoms and signs of myocardial ischemia by reducing left ventricular preload and increasing coronary blood flow, it generally does not attenuate the myocardial injury associated with epicardial coronary artery occlusion unless vasospasm plays a significant role. In patients presenting with ongoing chest pain, hypertension and heart failure, nitroglycerin should be used in sublingual dosing ( $0.4 \mathrm{mg}$ every $5 \mathrm{~min}$ up to 3 doses) or in IV dosing to begin at $10 \mathrm{mcg} / \mathrm{min}$ and titrate to desired blood pressure (BP) effect. Nitroglycerin should be avoided in suspected right ventricular (RV) infarction in case of systolic $\mathrm{BP}<90$ $\mathrm{mm} \mathrm{Hg}$ or there was a recent ( 24 to $48 \mathrm{~h}$ ) use of 5-phosphodiesterase inhibitors. IV beta-blockers should be used in ACS patients (especially in those with STEMI) presenting with refractory hypertension or ongoing ischemia without contraindication (e.g. Metoprolol tartrate IV or atenolol $5 \mathrm{mg}$ every $5 \mathrm{~min}$ as tolerated up to 3 doses; titrate to heart rate and BP). Oxygen should be administered in cases of clinically significant hypoxemia (oxygen saturation $<90 \%$ ), heart failure (HF), dyspnea using 2 to $4 \mathrm{~L} / \mathrm{min}$ via nasal cannula and increasing rate or change with the face mask as needed. In patients with intense pain, anxiety and pulmonary edema, morphine can be used in 4 to $8 \mathrm{mg}$ IV initially, with lower doses in elderly or 2 to $8 \mathrm{mg}$ IV every 5 to $15 \mathrm{~min}$ if needed [13].

Antithrombotic therapy in NSTEMI: The antithrombotic regimen after PCI in patients with NSTEMI is illustrated in Figure 2 [12]. Figure 3 reassumed the principal antiplatelet therapies in NSTEMI patients. Prasugrel is a thienopyridine pro-drug that irreversibly blocks the P2Y12 platelet receptor with a faster onset and a more potent antiplatelet inhibition when compared with clopidogrel. The TRITON-TIMI 38 trial, enrolling ACS patients undergoing PCI, showed that prasugrel when compared to clopidogrel was

\begin{tabular}{|c|c|}
\hline Early Anti-ischemic and Analgesic Therapy & $\begin{array}{l}\text { 1. Oxygen if low arterial saturation ( }<90 \%) \text { or respiratory distress } \\
\text { 2. IV nitroglycerin if persistent ischemia, heart failure, or hypertension } \\
\text { 3. Oral } \beta \text {-blockade if no } \mathrm{C} / \mathrm{I} \\
\text { 4. If } \beta \text {-blockade } \mathrm{C} / \mathrm{I} \text {, nondihydropyridine } \mathrm{CCB} \\
\text { 5. Oral ACE inhibitor within } 24 \mathrm{hr} \text { if } \mathrm{LV} \text { failure if } \mathrm{BP}<100 \mathrm{~mm} \mathrm{Hg} \text { or not }>30 \mathrm{~mm} \mathrm{Hg} \text { below baseline; oral ARB if } \\
\text { ACE intolerant }\end{array}$ \\
\hline Antiplatelet Therapy & $\begin{array}{l}\text { 1. Aspirin on arrival or before, continue indefinite, loading dose of } 162-325 \mathrm{mg} \text {; long term } 75-162 \mathrm{mg} \text { daily, } \\
\text { higher disease after stenting } \\
\text { 2. P2Y12 Inhibitors (Ticagrelor, Prasugrel, Clopidogrel) } \\
\text { 3. Gpllbllla Inhibitors }\end{array}$ \\
\hline Anticoagulant Therapy & $\begin{array}{l}\text { 1. Enoxaparin or UFH as soon as possible; } \\
\text { 2. Fondaparinux or bivalirudin in case of high bleeding risk }\end{array}$ \\
\hline
\end{tabular}

$\mathrm{ACE}$, angiotensin-converting enzyme; ARB, angiotensin receptor blocker; BP, blood pressure; C/I, contraindication; Gp, glycoprotein; LV, left ventricular; PCl, percutaneous coronary intervention; UFH, unfractionated heparin [12,13]

Table 3: Management of Unstable Angina (UA) / Non-ST-Elevation Myocardial Infarction (NSTEMI).

1. Minimize pain-to-needle time, urgent hospitalization. Relieve pain by morphine

2. Aspirin upon suspicion.

3. Duration of pain: If $>3 \mathrm{hr}$, rapid transfer for $\mathrm{PPCl}$. If $<2-3 \mathrm{~h} \mathrm{r}$, or if delay to balloon inflation is greater than 90 min, urgent thrombolysis with anticoagulation by UFH or low-molecular-weight heparin or bivalirudin.

4. Primary angioplasty and stenting

5. P2Y12 Inhibitors (Ticagrelor, Prasugrel, Clopidogrel)

6. Gpllbllla Inhibitors

7. Consider indications for early $\beta$-blockade, ACE inhibition

8. Management of complications:

- $\quad$ Acute HF: Treat aggressively; diuretics, nitrates, ACE inhibitors, or ARBs (consider Swan-Ganz catheterization).

- Symptomatic ventricular arrhythmias: Lidocaine; if refractory, amiodarone.

- $\quad$ Supraventricular arrhythmias: Adenosine; consider esmolol; avoid verapamil or diltiazem if LVF.

- $\quad$ Cardiogenic shock: IABP, Impella, ECMO, bypass surgery.

- RV infarction: Fluids, inotropic support. Avoid nitrates.

- $\quad$ Rupture of free wall, mitral valve, ventricular septum: Cardiac surgery.

$\mathrm{ACE}$, angiotensin-converting enzyme; $\mathrm{ARB}$, angiotensin receptor blocker; $\mathrm{BP}$, blood pressure; CCB, calcium channel blocker; $\mathrm{ECMO}=\mathrm{extracorporeal}$ membrane oxygenation; IABP, intra-aortic balloon pump; LVF, left ventricular failure; PCI, percutaneous coronary intervention; PPCI, primary percutaneous coronary intervention; RV, right ventricular; UFH, unfractionated heparin $[12,19,20]$.

Table 4: Management of STEMI. 


\begin{tabular}{|c|c|c|}
\hline Recommendations & Class $^{2}$ & Level ${ }^{\mathrm{D}}$ \\
\hline \multicolumn{3}{|l|}{ Antiplatelet therapy } \\
\hline $\begin{array}{l}\text { ASA is recommended for all patients without contraindications at an initial oral loading dose of } 150-300 \mathrm{mg} \\
\text { (or } 80-150 \mathrm{mg} \text { i.v.). and at a maintenance dose of } 75-100 \mathrm{mg} \text { daily long-term regardless of treatment strategy. }\end{array}$ & 1 & A \\
\hline $\begin{array}{l}\text { A P2Y } 1 \text { inhibitor is recommended in addition to ASA, and maintained over } 12 \text { months unless there are } \\
\text { contraindications such as excessive risk of bleeding. Options are: }\end{array}$ & 1 & $\mathbf{A}$ \\
\hline $\begin{array}{l}\text { - Prasugrel ( } 60 \mathrm{mg} \text { loading dose, } 10 \mathrm{mg} \text { daily dose) in patients in whom coronary anatomy is known and who are } \\
\text { proceeding to } \mathrm{PCl} \text { if no contraindication }\end{array}$ & 1 & B \\
\hline $\begin{array}{l}\text { - Ticagrelor (180 mg loading dose, } 90 \mathrm{mg} \text { twice daily) for patients at moderate-to-high risk of ischaemic events, } \\
\text { regardless of initial treatment strategy including those pre-treated with clopidogrel if no contraindication }\end{array}$ & 1 & B \\
\hline $\begin{array}{l}\text { - Clopidogrel ( } 600 \mathrm{mg} \text { loading dose, } 75 \mathrm{mg} \text { daily dose), only when prasugrel or ticagrelor are not available or are } \\
\text { contraindicated }\end{array}$ & 1 & B \\
\hline GP Ilb/lla antagonists should be considered for bail-out situation or thrombotic complications. & Ila & c \\
\hline Pre-treatment with prasugrel in patients in whom coronary anatomy is not known, is not recommended. & III & B \\
\hline Pre-treatment with GP Ilb/llla antagonists in patients in whom coronary anatomy is not known, is not recommended. & III & A \\
\hline \multicolumn{3}{|l|}{ Anticoagulant therapy } \\
\hline Anticoagulation is recommended for all patients in addition to antiplatelet therapy during PCI. & 1 & A \\
\hline $\begin{array}{l}\text { The anticoagulation is selected according to both ischaemic and bleeding risks, and according to the efficacy-safety } \\
\text { profile of the chosen agent. }\end{array}$ & 1 & c \\
\hline $\begin{array}{l}\text { Bivalirudin ( } 0.75 \mathrm{mg} / \mathrm{kg} \text { bolus, followed by } 1.75 \mathrm{mg} / \mathrm{kg} / \text { hour for up to } 4 \text { hours after the procedure) is recommended } \\
\text { as alternative to UFH plus GP Ilb/llla receptor inhibitor during PCI. }\end{array}$ & $\mathbf{I}$ & A \\
\hline UFH is recommended as anticoagulant for $\mathrm{PCl}$ if patients cannot receive bivalirudin. & 1 & c \\
\hline $\begin{array}{l}\text { In patients on fondaparinux (2.5 mg daily s.c.), a single bolus UFH ( } 85 \mathrm{IU} / \mathrm{kg} \text {, or } 60 \mathrm{IU} / \mathrm{kg} \text { in the case of concomitant } \\
\text { use of GP Ilb/llla receptor inhibitors) is indicated during PCL. }\end{array}$ & 1 & B \\
\hline Enoxaparin should be considered as anticoagulant for $\mathrm{PCl}$ in patients pre-treated with subcutaneous enoxaparin. & Ila & B \\
\hline Discontinuation of anticoagulation should be considered after an invasive procedure unless otherwise indicated. & Illa & C \\
\hline Crossover of UFH and LMWH is not rec & III & $\mathbf{B}$ \\
\hline
\end{tabular}

Figure 2: Antithrombotic treatment in patients with NSTE-ACS undergoing PCI.

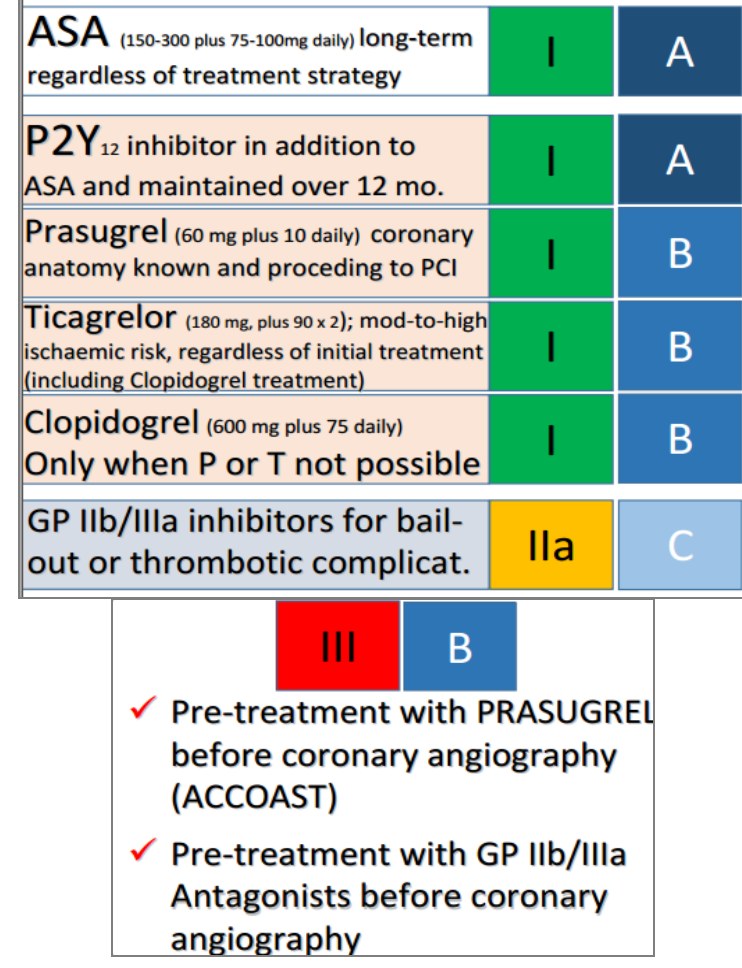

Figure 3: Antiplatelet therapy in NSTEMI. associated with a significantly reduced incidence of primary outcome (cardiovascular death, nonfatal MI, or nonfatal stroke): $4.7 \%$ versus $5.6 \%$ in clopidogrel group ( $\mathrm{HR}=0.82 ; 95 \% \mathrm{CI}: 0.73-0.93 ; \mathrm{P}=0.002$ ) [14]. Prasugrel $(60 \mathrm{mg}$ loading and $10 \mathrm{mg}$ daily maintenance dose p.o.) should be administered in patients in whom coronary anatomy is known and who are proceeding to PCI if no contraindication [12]. In diabetic patients presenting with ACS, prasugrel confers a particularly greater treatment effect than clopidogrel, without significantly increased bleeding. Prasugrel should be also considered in patients who present with stent thrombosis despite adherence to clopidogrel therapy. Prasugrel is rather contraindicated in patients with prior stroke or TIA and not recommended for patients of $\geq 75$ years of age. In case of low body weight $(60 \mathrm{~kg})$ a reduced maintenance dose of $5 \mathrm{mg}$ should be prescribed. Ticagrelor (180 $\mathrm{mg}$ loading dose; $90 \mathrm{mg}$ twice daily as maintenance dose p.o.) an oral, reversibly binding P2Y12inhibitor is the first member of a new class of drugs known as cyclopentyltriazolo-pyrimidines with a plasma half-life of approximately 6-12 hours. In the PLATO trial, which randomized 18,624 ACS patients to ticagrelor vs. clopidogrel, the incidence of primary endpoint (death from vascular causes, MI, or stroke) at 12 months was significantly lower in the ticagrelor group (9.8\% versus $11.7 \%$; $\mathrm{HR}=0.84$; $95 \% \mathrm{CI}$; 0.77-0.92; $\mathrm{P}=0.001$ ). Ticagrelor should be administered for patients at moderate-to-high risk of ischemic events, regardless of initial treatment strategy including those pre-treated with clopidogrel if no contraindication [15]. GP IIb/IIIa inhibitors inhibit the final common pathway in platelet aggregation, achieving $>80-90 \%$ platelet inhibition within $15 \mathrm{~min}$ of administration. Figure 4 summarizes the main characteristics of GP IIb/IIIa inhibitors. In the era before DAPT, trials 


\section{GP IIb/IIla inhibition ${ }^{a}$}

Abciximab $0.25 \mathrm{mg} / \mathrm{kg}$ intravenous bolus followed by infusion of $0.125 \mu \mathrm{g} / \mathrm{kg} / \mathrm{min}$ (maximum $10 \mu \mathrm{g} / \mathrm{min}$ ) for $12-24 \mathrm{~h}$ Eptifibatide $180 \mu \mathrm{g} / \mathrm{kg}$ intravenous bolus (second bolus after $10 \mathrm{~min}$ for $\mathrm{PCl}$ ) followed by infusion of $2.0 \mu \mathrm{g} / \mathrm{kg} / \mathrm{min}$ for $72-96 \mathrm{~h}$ Tirofiban $0.4 \mu \mathrm{g} / \mathrm{kg} / \mathrm{min}$ intravenously for $30 \mathrm{~min}$ followed by infusion of $0.10 \mu \mathrm{g} / \mathrm{kg} / \mathrm{min}$ for $48-96 \mathrm{~h}$. A high-dose regimen (bolus $25 \mu \mathrm{g} / \mathrm{kg}+0.15 \mu \mathrm{g} / \mathrm{kg} / \mathrm{min}$ infusion for $18 \mathrm{~h}$ ) is tested in clinical trials

${ }^{a}$ See Chronic kidney disease for specific rules of prescription in the case of renal failure.

Abiciximab: monoclonal antibody fragment high affinity to the GpIIbIIIa receptor

Eptifibatide: cyclic peptide lower GpIIbIIIa receptor affinity

- Tirofiban: peptido-mimetic inhibitor intermediated affinity GpIIbIIIa receptor

Figure 4: Gpllbllla inhibithors.

of adequately dosed GP IIb/IIIa inhibitors in patients undergoing balloon angioplasty and coronary stent implantation demonstrated a lower incidence of composite ischemic events in favor of GP IIb/IIIa treatment in combination with UFH, than with UFH alone, primarily through a reduction in MI (16). However, there is no evidence for an additional benefit of routine upstream use of GP IIb/IIIa inhibitors in NSTEMI patients scheduled for coronary angiography [16-18]. Therefore, GP IIb/IIIa antagonists should be considered for bail-out situation or thrombotic complications. Regarding the antithrombotic treatment, a general rule in NSTEMI patients is to avoid crossover between antithrombins (with the exception of adding UFH to fondaparinux)-especially between UFH and low-molecular-weight heparin (LMWH) - and to discontinue antithrombins after PCI except in specific situations (e.g. LV aneurysm and/or thrombus, AF, prolonged bed rest, deferred sheath removal). Among patients with high-risk NSTEMI bivalirudin plus provisional GP IIb/IIIa inhibitors is recommended as an alternative to UFH plus GP IIb/IIIa receptor inhibitors, particularly in patients with a high risk of bleeding [12].

Antithrombotic therapy in STEMI: Primary PCI is the treatment of choice in STEMI patients with symptoms presenting $<12$ hours $[12,19,20]$. The ESC and ACCF/AHA guidelines recommend fibrinolysis in cases where primary PCI cannot be performed within 120 minutes of first medical contact among patients within 12 hours of symptoms onset in the absence of contraindications (class I, LoE A) $[12,19,20]$. The ESC guidelines also recommend fibrinolysis if the doorto-balloon time is $>90$ minutes among patients with large myocardial infarction and low bleeding risk presenting $<2$ hours after symptom onset (class IIa, LoE B). Doses of fibrinolytic agents are shown in Figure 5. Following initiation of lytic therapy, patients should be transferred to a PCI centre. Even if it is likely that fibrinolysis will be successful (STsegment resolution $>50 \%$ at $60-90 \mathrm{~min}$; typical reperfusion arrhythmia; disappearance of chest pain), a strategy of routine early angiography is recommended if there are no contraindications. Patients undergoing primary PCI should receive a combination of DAPT with ASA and a $\mathrm{P} 2 \mathrm{Y} 12$ receptor blocker as early as possible before angiography, and a parenteral anticoagulant (Figure 6) [12].

Prasugrel and ticagrelor should be preferred to clopidogrel administration. Upstream use of a GP IIb/IIIa inhibitors (vs. in-lab use) may be considered in high-risk patients undergoing transfer for primary PCI (IIb B LoE B) (Figures 7 and 8), [21,22]. GP IIb/
IIIa inhibitors should be considered for bail-out therapy if there is angiographic evidence of massive thrombus, slow or no-reflow or a thrombotic complication (IIa LoE C). Regarding the antithrombotic therapy UFH: $70-100 \mathrm{U} / \mathrm{kg}$ IV bolus should be used when no GP IIb/ IIIa inhibitor is planned; whereas $50-70 \mathrm{U} / \mathrm{kg}$ IV bolus of UFH should be used with GP IIb/IIIa inhibitors (I LoE C.) Bivalirudin $(0.75 \mathrm{mg} / \mathrm{kg}$ IV bolus followed by IV infusion of $1.75 \mathrm{mg} / \mathrm{kg} / \mathrm{h}$ for up to 4 hours after the procedure) has been downgraded with a class IIA LoE A (Figures 6-9) [12].

Inadequate myocardial perfusion after successful mechanical opening of the infarct-related artery during primary PCI is often referred to as 'no-reflow'. The diagnosis of no-reflow is usually made when postprocedural thrombolysis in myocardial infarction (TIMI) flow is 3 but when myocardial blush grade is 0 or 1 , or when ST resolution within $4 \mathrm{~h}$ of the procedure is $<70 \%$. Table 5 reassumes mechanisms and therapeutic strategies to treat no-reflow.

Long term therapy after ACS: Antischemic and anti-neurohumoral therapies pose a crucial role in the management of patients with ACS $[12,19,20]$. As previously reported, beta-receptor antagonists should be administered in all patients without contraindication. Oral betablocker therapy should be initiated within the first $24 \mathrm{~h}$ for patients who do not have 1 or more of the following: 1) signs of HF, 2) evidence of a low-output state, 3) increased risk for cardiogenic shock, or 4) other relative contraindications to beta blockade (PR interval greater than $0.24 \mathrm{~s}$, second or third degree heart block, active asthma, or reactive airway disease). Patients with $\mathrm{MI}$ should receive oral beta blocker such as metoprolol tartrate ( 25 to $50 \mathrm{mg}$ every 6 to $12 \mathrm{~h}$ orally, then transition over next 2 to $3 \mathrm{~d}$ to twice-daily dosing of metoprolol tartrate or to daily metoprolol succinate; titrate to daily dose of 200 $\mathrm{mg}$ as tolerated) or carvedilol $6.25 \mathrm{mg}$ twice daily, titrate to $25 \mathrm{mg}$ twice daily as tolerated. An ACE inhibitor should be also administered orally within the first $24 \mathrm{~h}$ to ACS patients with pulmonary congestion or LV ejection fraction (LVEF) $\leq 40 \%$, in the absence of hypotension or known contraindications to that class of medications. ACE inhibitors typically used are the following:

- Lisinopril 2.5 to $5 \mathrm{mg} / \mathrm{d}$ to start; titrate to $10 \mathrm{mg} / \mathrm{d}$ or higher as tolerated

\begin{tabular}{|l|l|l|}
\hline & Initial treatment & $\begin{array}{l}\text { Specific } \\
\text { contraindications }\end{array}$ \\
\hline $\begin{array}{l}\text { Streptokinase } \\
\text { (SK) }\end{array}$ & $\begin{array}{l}1.5 \text { million units over } 30-60 \\
\text { min i.v. }\end{array}$ & $\begin{array}{l}\text { Prior SK or } \\
\text { anistreplase }\end{array}$ \\
\hline $\begin{array}{l}\text { Alteplase } \\
\text { (tPA) }\end{array}$ & $\begin{array}{l}15 \mathrm{mg} \text { i.v. bolus } \\
0.75 \mathrm{mg} / \mathrm{kg} \text { over } 30 \mathrm{~min} \text { (up } \\
\text { to } 50 \mathrm{mg} \text { ) then } 0.5 \mathrm{mg} / \mathrm{kg} \\
\text { over } 60 \mathrm{~min} \text { i.v. (up to } 35 \mathrm{mg} \text { ) }\end{array}$ & \\
\hline $\begin{array}{l}\text { Reteplase } \\
\text { (r-PA) }\end{array}$ & $\begin{array}{l}10 \mathrm{units}+10 \text { units i.v. bolus } \\
\text { given } 30 \text { min apart }\end{array}$ & \\
\hline $\begin{array}{l}\text { Tenecteplase } \\
\text { (TNK-tPA) }\end{array}$ & $\begin{array}{l}\text { Single i.v. bolus: } \\
30 \mathrm{mg} \text { if }<60 \mathrm{~kg} \\
35 \mathrm{mg} \text { if } 60 \text { to }<70 \mathrm{~kg} \\
40 \mathrm{mg} \text { if } 70 \text { to }<80 \mathrm{~kg} \\
45 \mathrm{mg} \text { if } 80 \text { to }<90 \mathrm{~kg} \\
50 \mathrm{mg} \text { if } \geq 90 \mathrm{~kg}\end{array}$ & \\
\hline
\end{tabular}

Figure 5: Dose of fibrinolityc agents in STEMI. 


\begin{tabular}{|c|c|c|}
\hline Recommendations & Class $^{*}$ & Level \\
\hline \multicolumn{3}{|l|}{ Antiplatelet therapy } \\
\hline $\begin{array}{l}\text { ASA is recommended for all patients without contraindications at an initial oral loading dose of } 150-300 \mathrm{mg} \\
\text { (or } 80-150 \mathrm{mg} \text { i.v.) and at a maintenance dose of } 75-100 \mathrm{mg} \text { daily long-term regardless of treatment strateg }\end{array}$ & $\mathbf{I}$ & A \\
\hline $\begin{array}{l}\text { A P2Y } Y_{12} \text { inhibitor is recommended in addition to ASA and maintained over } 12 \text { months unless there are } \\
\text { contraindications such as excessive risk of bleeding. Options are: }\end{array}$ & $\mathbf{I}$ & A \\
\hline - Prasugrel ( $60 \mathrm{mg}$ loading dose, $10 \mathrm{mg}$ daily dose) if no contraindication & $\mathbf{I}$ & $\mathbf{B}$ \\
\hline - Ticagrelor ( $180 \mathrm{mg}$ loading dose, $90 \mathrm{mg}$ twice daily) if no contraindication & 1 & B \\
\hline $\begin{array}{l}\text { - Clopidogrel ( } 600 \mathrm{mg} \text { loading dose, } 75 \mathrm{mg} \text { daily dose), only when prasugrel or ticagrelor are not available or are } \\
\text { contraindicated. }\end{array}$ & $\mathbf{I}$ & $\mathbf{B}$ \\
\hline It is recommended to give $P 2 Y_{12}$ inhibitors at the time of first medical contact. & 1 & B \\
\hline GP Ilb/lla inhibitors should be considered for bail-out or evidence of no-reflow or a thrombotic complication. & Ila & C \\
\hline $\begin{array}{l}\text { Upstream use of a GP Ilb/llla inhibitor (vs. in-lab use) may be considered in high-risk patients undergoing transfer } \\
\text { for primary PCl. }\end{array}$ & Illb & $\mathbf{B}$ \\
\hline \multicolumn{3}{|l|}{ Anticoagulants } \\
\hline Anticoagulation is recommended for all patients in addition to antiplatelet therapy during PCl. & $\mathbf{I}$ & $\overline{\mathbf{A}}$ \\
\hline $\begin{array}{l}\text { The anticoagubtion is selected according to both ischaemic and bleeding risks, and according to the efficacy-safety } \\
\text { profile of the chosen agent. }\end{array}$ & I & C \\
\hline $\begin{array}{l}\text { Unfractionated heparin: } 70-100 \mathrm{U} / \mathrm{kg} \text { i.v. bolus when no GP } \mathrm{llb} / \mathrm{lll} \mathrm{l} \text { inhibitor is planned; } 50-70 \mathrm{U} / \mathrm{kg} \text { i.v. bolus with } \\
\text { GP Ilb/lla inhibitor. }\end{array}$ & I & C \\
\hline Bivalirudin $0.75 \mathrm{mg} / \mathrm{kg}$ i.v. bolus followed by i.v. infusion of $1.75 \mathrm{mg} / \mathrm{kg} / \mathrm{h}$ for up to 4 hours after the procedure. & Ila & A \\
\hline Enoxaparin i.v. $0.5 \mathrm{mg} / \mathrm{kg}$ with or without GP $\mathrm{llb} / \mathrm{lll} \mathrm{la}$ inhibitor. & Ila & $\mathbf{B}$ \\
\hline
\end{tabular}

Figure 6: Antithrombotic treatment in patients with STEMI undergoing primary PCI.

\begin{tabular}{|c|c|c|}
\hline 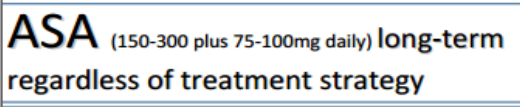 & & $A$ \\
\hline $\begin{array}{l}\text { P2Y } Y_{12} \text { inhibitor in addition to } \\
\text { ASA and maintained } 12 \text { months }\end{array}$ & & $A$ \\
\hline $\begin{array}{l}\text { Prasugrel (60 mg plus } 10 \text { daily) } \\
\text { Ticagrelor ( } 180 \mathrm{mg} \text {, Plus } 90 \times 2 \text { daily) }\end{array}$ & & B \\
\hline $\begin{array}{l}\text { Clopidogrel ( } 600 \mathrm{mg} \text { plus } 75 \text { daily) } \\
\text { Only when P or T not possible }\end{array}$ & & B \\
\hline $\mathrm{P}_{2} \mathrm{Y}_{12}$ at the time of FMC & I & B \\
\hline $\begin{array}{l}\text { GP IIb/IIla inhibitors for bail- } \\
\text { out or no-reflow }\end{array}$ & IIa & C \\
\hline $\begin{array}{l}\text { Upstream GP IIb/IIla in high } \\
\text { risk trasfer-PPCI }\end{array}$ & IIb & B \\
\hline
\end{tabular}

Figure 7: Antiplatelet therapy in STEMI.

- Captopril 6.25 to $12.5 \mathrm{mg} 3$ times/d to start; titrate to 25 to $50 \mathrm{mg}$ 3 times/d as tolerated

- Ramipril $2.5 \mathrm{mg}$ twice daily to start; titrate to $5 \mathrm{mg}$ twice daily as tolerated $\sqrt{ }$ Patients with high clinical risk but low bleeding risk

$\sqrt{ }$ Cardiogenic Shock

$\sqrt{ }$ Large or giant thrombus

$\sqrt{ }$ Stent thrombosis

$\sqrt{ }$ No-reflow phenomenon following PCI

Figure 8: Rational use of $\mathrm{Gpl}$ in primary $\mathrm{PCl}$.

\begin{tabular}{|l|}
\hline \multicolumn{1}{|c|}{ Bivalirudin } \\
\hline Shorter acting agent \\
\hline $\begin{array}{l}\text { Initial dose of } 0.75 \mathrm{mg} / \mathrm{kg} \text { IV bolus, followed by } \\
\text { continuous infusion at rate of } 1.75 \mathrm{mg} / \mathrm{kg} / \mathrm{hr} \text { for } \\
\text { duration of procedure }\end{array}$ \\
\hline More predictable anti-thrombotic response \\
\hline Does not activate platelets \\
\hline $\begin{array}{l}\text { Associated with less bleeding but preserved therapeutic } \\
\text { benefit in PCI }\end{array}$ \\
\hline
\end{tabular}

Figure 9: Antithrombins in primary PCI.

An angiotensin receptor blocker (eg. Valsartan $20 \mathrm{mg}$ twice daily to start; titrate to $160 \mathrm{mg}$ twice daily as tolerated) should be administered to ACS patients who are intolerant of ACE inhibitors 
and have either clinical or radiological signs of HF or LVEF $\leq 40 \%$. An aldosterone antagonist should be given to patients with STEMI and no contraindications who are already receiving an ACE inhibitor and beta blocker and who have an LVEF less than or equal to 0.40 and either symptomatic HF or diabetes mellitus. Finally, all ACS patients without contraindications should receive a high-intensity statin therapy such as atorvastatin $80 \mathrm{mg}$ daily or rosuvastatin $40 \mathrm{mg}$ daily.

\section{Management of Acute Heart Failure/Cardiogenic Shock in Cath Lab}

The clinical presentation of acute heart failure ranges from the sudden appearance of dyspnea to frank cardiogenic shock. Regardless of their clinical presentation, nearly all patients with heart failure will pass through the catheterization laboratory at some point in their clinical evaluation and management. Therapeutic interventions to produce hemodynamic improvement and stability must be undertaken expeditiously in these patients. Myocardial injury/infarction, high degree atrioventricular (AV) block, ventricular tachycardia, pericardial tamponade and pulmonary embolism are examples of the acute heart failure causes. In patients treated in Cath Lab, cardiogenic shock is most often associated with left ventricular MI and a loss of more than $40 \%$ of the myocardium. Other causes are RV failure, valvular heart disease/ dysfunction (e.g. acute mitral or aortic insufficiency or regurgitation). Cardiogenic shock is defined as a decreased cardiac output and evidence of tissue hypoperfusion in the presence of adequate intravascular volume [23]. In patients presenting with cardiogenic shock, a relative or absolute reduction in left ventricular filling pressure as the cause of hypotension must be excluded. It is indeed estimated that $10 \%$ to $15 \%$ of patients with an acute MI may be significantly volume depleted [24]. RV infarction, pericardial tamponade and certain instances of pulmonary embolization are other common examples of acute heart failure that fall into this category. Unless there are signs of left heart volume overload (eg, S3 gallop, moist pulmonary rales, vascular or pulmonary congestion on chest radiograph), normal saline solution should be administered intravenously at a reasonably fast rate $(\geq$ $500 \mathrm{~mL}$ bolus, followed by $500 \mathrm{~mL} / \mathrm{h}$ ). Obviously, if arrhythmias are present their contribution to the hemodynamic state and need for rapid cardioversion or pacing must be determined [25].

Patients presenting with acute heart failure can be essentially classified in 2 groups: patients with acute pulmonary edema and those with cardiogenic shock. Principles of treatment in these 2 groups are summarized in Tables 6 and 7. Vasodilators and inotropic agents represent the 2 main therapeutic drugs to treat patients with acute heart failure.

\section{Arterial and Venous Vasodilatators}

\section{Nitrates}

Nitrates work by increasing vasodilatory vascular cyclic GMP and NO. Their major effect is venous rather than arteriolar dilation, thus being most suited to patients with raised pulmonary wedge pressure and clinical features of pulmonary congestion, acute pulmonary edema. Nitroglycerin can be administered IV with a starting dose of 0.3 to $0.5 \mu \mathrm{g} / \mathrm{kg}$ body weight per min.

\section{Nitroprusside}

Nitroprusside is a donor of NO that vasodilates by formation of cyclic GMP in vascular tissue. IV sodium nitroprusside remains the reference vasodilator for severe acute low-output left-sided heart failure

- Coronary vasospasm

- Free radical generation

- Endothelial dysfunction

- Local release of vasoconstrictors

- Distal embolization debris/thrombus

- Capillary plugging by red cells, neutrophils

- Tissue edema, intramural hemorrhage

- Acute Ml/thrombus laden lesions

- SVG interventions

- Atherectomy

\section{Mechanisms}

Pharmacological Management of No-Reflow

- Adenosine Adenosine receptor agonist; determines a maximum coronary vasodilation without; hemodynamic effects-mild $\downarrow$ BP; multiple IC boluses-typically 50 $300 \mu \mathrm{g}$ IC

- Nitroglycerin- \pm effective except for relief of superimposed spasm (inability of microvasculature to metabolize nitrates)

- Calcium channel blockers

Verapamil: Acts directly on Ca++ channels in vascular smooth muscle cells. Commonly used for no reflow; dosage: 100-500 $\mu \mathrm{g}$ IC Complications: A-V nodal block, Myocardial depression Beware significant LV or RV dysfunction

Diltiazem: Acts directly on Ca++ channels in vascular smooth muscle cells. Commonly used for no reflow; dosage 50-100 $\mu$ IC; up to $5 \mathrm{mg}$; complications: A-V block; sinus arrest Less negative inotropy than verapamil

Nitroprusside-50-200 $\mu \mathrm{g} \mathrm{IC}$

$\mathrm{MI}=$ yyocardial infarction; SVG=safenous vein graft; $\mathrm{BP}=$ blood pressure; IC=intracoronary; $\mathrm{AV}=$ atrioventricular; $\mathrm{LV}=\mathrm{left}$ ventricle; $\mathrm{RV}=$ right ventricle [12,9,20]

Table 5: Mechanisms and management of "No-Reflow" during percutaneous coronary intervention.

1. Oxygen therapy

2. Nitroglycerin intravenously (if systemic blood pressure is acceptable (SBP $\geq 95$ to $100 \mathrm{~mm} \mathrm{Hg}$ ), nitroglycerin can be administered IV with a starting dose of 0.3 to 0.5 $\mu \mathrm{g} / \mathrm{kg}$ body weight per $\mathrm{min}$ )

3. Intravenous administration of a diuretic (eg, furosemide, 20 to $80 \mathrm{mg}$ intravenously)

4. Morphine sulfate ( 3 to $5 \mathrm{mg}$ intravenously)

5. Administration of cardiovascular support drugs to attain and stabilize clinical-hemodynamic status (eg, intravenous infusion of nitroprusside, dobutamine, dopamine)

6. CPAP, Intubation and mechanical ventilation for severe hypoxia that does not respond rapidly to therapy and for respiratory acidosis

7. Definitive correction of the underlying cause (eg, mitral valve replacement or repair of acute, severe mitral regurgitation) when indicated and clinically feasible $\mathrm{SBP}=$ Systolic Blood pressure; IV=intravenous; CPAP=Continuous Positive Airway Pressure [23,25].

Table 6: Therapeutic management of acute cardiogenic pulmonary edema. 


\section{Oxygen therapy}

2. In the absence of obvious intravascular volume overload, brisk intravenous administration of fluid volume

3. In the presence of intravascular volume overload or after adequate intravenous fluid volume therapy, intravenous administration of cardiovascular support drugs (eg, dopamine, dobutamine, norepinephrine) to attain and maintain stable clinical-hemodynamic status

4. Urgent coronary artery revascularization for acute myocardial injury/infarction, if readily available

5. Acute Circulatory Support (which include the intra-aortic balloon pump

(IABP), venoarterial extracorporeal membrane oxygenation (VA-ECMO), a catheter-mounted axial-flow pump (Impella; Abiomed Inc., Danvers, MA), and the p LA-FA centrifugal bypass (TandemHeart; Cardiac Assist Inc., Pittsburgh, PA) system in patients who respond inadequately to the aforementioned interventions and who are reasonable candidates for heart transplantation.

$[23,25]$

Table 7: Therapeutic management of cardiogenic shock.

caused by mitral or aortic regurgitation, because it acts rapidly and has a balanced effect on the afterload and preload, dilating both arterioles and veins. Indications include the following situations: (1) severe acuteon-chronic heart failure, especially with regurgitant valve disease; (2) hypertensive crises; (3) dissecting aneurysm. Contraindications include preexisting hypotension (systolic $<90 \mathrm{~mm} \mathrm{Hg}$, diastolic $<60$ $\mathrm{mm} \mathrm{Hg}$ ). Sodium nitroprusside need careful continuous monitoring for its light sensitivity, and for the severe risk of cyanide toxicity [26].

\section{Nesiritide}

This agent is a recombinant preparation of the human B-type natriuretic peptide. It acts on GMP in a way similar to NO, thus being both a venous and arterial vasodilator. However, it has a greater effect than nitroglycerin in reducing right atrial pressure, pulmonary capillary wedge pressure, and cardiac index. Further it gave greater relief of dyspnea than did nitroglycerin. Nesiritide is indicated for the IV treatment of patients with acutely decompensated congestive heart failure with dyspnea at rest or minimal activity. Contraindications include cardiogenic shock or a systolic BP $<90 \mathrm{~mm} \mathrm{Hg}$. The approved dose is a $2 \mu \mathrm{g} / \mathrm{kg}$ bolus, followed by an IV continuous infusion of 0.01 $\mu \mathrm{g} / \mathrm{min}$ that may be increased up to a maximum of $0.03 \mu \mathrm{g} / \mathrm{kg}$ per minute, with the rate-limiting side effect being hypotension. There is no experience with infusions for longer than 48 hours [26].

\section{Inotropes/Vasoconstrictors}

Sympathomimetic agents act on the acutely failing heart stimulating several receptors. The $\beta 1$-stimulation has an inotropic effect, $\beta 2$-stimulation has afterload reduction (peripheral arterial vasodilation), while the $\alpha$-stimulation restore the pressure. However, these agents may be associated with some side effects. For example, the $\beta 1$-effect may precipitate arrhythmias and tachycardia, which can potentially increase ischemia, which is very important in MI patients. Excessive $\alpha$-effects increase the afterload as the BP rises beyond what is required for adequate perfusion, thus increasing myocardial work. Although $\beta 2$-activation achieves beneficial vasodilation and also mediates some inotropic effect, such stimulation also causes hypokalemia with enhanced risk of arrhythmias. These are the reasons why sympathomimetics are used only in short-term treatment of acute heart failure [27]. The sympathomimetic agents are reported in Table 8 [28]. Epinephrine is used when combined inotropic/chronotropic stimulation is urgently needed, as in cardiac arrest and in refractory cardiogenic shock. Side effects include tachycardia, arrhythmias, anxiety, headaches, cold extremities, cerebral hemorrhage, and pulmonary edema. Contraindications include late pregnancy because of risk of inducing uterine contractions. Norepinephrine stimulates $\alpha$-receptors in the periphery (with more marked a-effects than epinephrine) and $\beta$-receptors in the heart; therefore it is typically used when a shock-like state is accompanied by peripheral vasodilation ("warm shock"). Dopamine is a catecholamine-like that stimulates the heart by both $\beta$-and $\alpha$-adrenergic receptors and causes vasodilation through dopamine receptors. Theoretically, dopamine has the valuable property in severe HF or shock of specifically increasing blood flow to the renal, mesenteric, coronary, and cerebral beds by activating the specific postjunctional dopamine DA1 receptors. At high doses dopamine increase the risk of tachycardia, arrhythmias, renal vasoconstriction. Dobutamine is a synthetic analogue of dopamine characterized by a potent inotropic effect. However, its $\beta 2$-stimulatory effect may lead to hypotension and sometimes to a fall in diastolic pressure with reflex tachycardia. The ideal candidate for dobutamine therapy is the patient who has severely depressed left ventricular (LV) function with a low cardiac index and elevated LV filling pressure, but in whom extreme hypotension is not present (mean arterial BP < $70 \mathrm{~mm} \mathrm{Hg}$ but no clinical shock). A combination of dopamine and vasodilator therapy or dopamine with dobutamine is typically used. The potential disadvantages of dobutamine are that (1) in severe $\mathrm{CHF}$, the $\beta$-receptors may be downgraded or therapeutically blocked so that dobutamine may not be as effective as anticipated; (2) BP may decrease or stay unchanged, and not increase; and (3) there may risk of serious arrhythmias. Isoproterenol has a relatively pure $\beta$-stimulant $(\beta 1>\beta 2)$ effect. Its cardiovascular effects closely resemble those of exercise, including a positive inotropic and vasodilatory effect. Theoretically, it is most suited to situations where the myocardium is poorly contractile due to severe bradyarrhythmias. Another ideal use is in $\beta$-blocker overdose. The major problem lies in the risk of tachycardia and arrhythmias. Furthermore, it may drop the diastolic BP by its $\beta 2$ vasodilator stimulation. Other side effects are headache, tremor, and sweating. Contraindications include myocardial ischemia, which can be worsened, and arrhythmias.

\section{Management of Arrhythmias in Cath Lab}

\section{Tachycardias}

Tachycardias can be classified in several ways, based on the appearance of the QRS complex (Table 9), heart rate, and regularity. The Management of tachyarrhythmias strictly depends on the patient clinical status. If the patient demonstrates rate-related cardiovascular compromise with signs and symptoms such as acute altered mental status, ischemic chest discomfort, acute heart failure, hypotension, or other signs of shock suspected to be due to a tachyarrhythmia, physician should proceed with immediate synchronized cardioversion. Conversely, several antiarrythymic drugs can be used intravenously. Tables 10 and 11 reassume the principal drugs used for supraventricular and ventricular tachycardias, respectively [29].

\section{Bradyarrhythmias}

Atrioventricular (AV) blocks may be caused by medications or electrolyte disturbances, as well as structural problems resulting from MI. If the bradycardia is the cause of acute altered mental status, 


\begin{tabular}{|c|c|c|}
\hline Drug & Dose (Then Titrate to Effect) & Indications \\
\hline $\begin{array}{l}\text { Epinephrine } \\
\beta 1 \beta 2-\text { stimulation with some added } \\
\alpha \text {-mediated effects at a high dose }\end{array}$ & $\begin{array}{l}\text { Acute dose is } 0.5 \mathrm{mg} \text { subcutaneously or intramuscularly }(0.5 \mathrm{ml} \\
\text { of } 1: 1000) \text {, or } 0.5 \text { to } 1.0 \mathrm{mg} \text { into the central veins, } 0.1 \text { to } 0.2 \mathrm{mg} \\
\text { intracardiac. } \\
\text { Infusion dose: } 0.01-0.5 \mathrm{mcg} / \mathrm{kg} / \mathrm{min} \text { (In } 70-\mathrm{kg} \text { adult, } 7-35 \mathrm{mcg} / \\
\mathrm{min}) \\
\text { A low physiologic infusion rate }(<0.01 \mu \mathrm{gg} / \mathrm{kg} \text { per minute) } \\
\text { decreases BP (vasodilator effect), whereas more than } 0.2 \mu \mathrm{g} / \\
\mathrm{kg} \text { per minute increases peripheral resistance and BP (combined } \\
\text { inotropic and vasoconstrictor effects). The } \alpha-\text { stimulatory effect of } \\
\text { high-dose epinephrine helps to maintain the blood pressure and } \\
\text { overcomes the peripheral vasodilation achieved by } \beta 2 \text {-receptor } \\
\text { stimulation. }\end{array}$ & $\begin{array}{l}\text { - Cardiac arrest (asystole, PEA, VF), [anaphylactoid rxn, } \\
\text { anaphylaxis] } \\
\text { - Shock: IV 2-10 mcg/min; CPR: } 1 \mathrm{mg} \mathrm{q} 3 \mathrm{~min} \\
\text { - Used to treat severe hypotension (eg, systolic blood } \\
\text { pressure } 70 \mathrm{~mm} \mathrm{Hg} \text { ) } \\
\text { - Useful for symptomatic bradycardia if atropine and } \\
\text { transcutaneous pacing fail or if pacing is not available } \\
\text { - Useful for anaphylaxis associated with hemodynamic } \\
\text { instability or respiratory distress }\end{array}$ \\
\hline $\begin{array}{l}\text { Norepinephrine } \\
\text { prominent } \alpha \text { and- } \beta 1 \text {-effects with less } \\
\beta 2 \text {-stimulation }\end{array}$ & $0.1-0.5 \mathrm{mcg} / \mathrm{kg} / \mathrm{min}$ (In $70 \mathrm{~kg}$ adult, $7-35 \mathrm{mcg} / \mathrm{min})$ & $\begin{array}{l}\text { - Shock refractory to other sympathomimetics-low systemic } \\
\text { vascular resistance states } \\
\text {-Used to treat severe hypotension (eg, systolic blood } \\
\text { pressure } 70 \mathrm{~mm} \mathrm{Hg} \text { ) and a low total peripheral resistance } \\
\text { - Relatively contraindicated in patients with hypovolemia. It may } \\
\text { increase myocardial oxygen requirements, mandating cautious } \\
\text { use in patients with ischemic heart disease } \\
\text {-Usually induces renal and mesenteric vasoconstriction; in } \\
\text { sepsis, however, norepinephrine improves renal blood flow and } \\
\text { urine output }\end{array}$ \\
\hline $\begin{array}{l}\text { Phenylephrine } \\
\text { Pure a effect }\end{array}$ & $\begin{array}{l}0.5-2.0 \mathrm{mcg} / \mathrm{kg} / \mathrm{min} \text { (In } 70 \mathrm{~kg} \text { adult, } 35-140 \\
\mathrm{mcg} / \mathrm{min} \text { ) } \\
\text { Minimal } \uparrow \mathrm{HR} \text {, occasional reflex brady }\end{array}$ & $\begin{array}{l}\text {-Used to treat severe hypotension (eg, systolic blood pressure } \\
<70 \mathrm{~mm} \mathrm{Hg} \text { ) and a low total peripheral resistance }\end{array}$ \\
\hline $\begin{array}{l}\text { Dopamine } \\
D A, \beta 1 \beta 2, \alpha \text { effect }\end{array}$ & 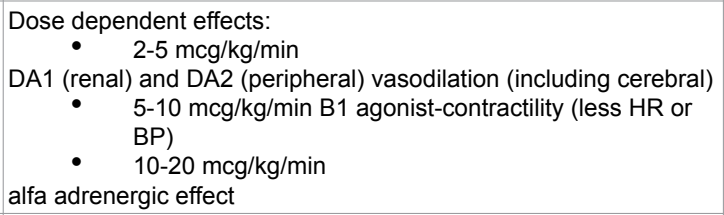 & $\begin{array}{l}\text { - Hypotension, poor tissue perfusion (oliguria, anuria, altered } \\
\text { level of consciousness), especially if it is associated with } \\
\text { symptomatic bradycardia }\end{array}$ \\
\hline $\begin{array}{l}\text { Dobutamine } \\
\beta \text {-adrenergic stimulating agent }(\beta 1 \\
>\beta 2>\alpha) \text {. }\end{array}$ & $\begin{array}{l}5-10 \mathrm{mcg} / \mathrm{kg} / \mathrm{min} \\
\text {-The }(+) \text { isomer is a potent beta-adrenergic agonist, whereas the } \\
(-) \text { isomer is a potent alpha-1-agonist } \\
\text {-The vasodilating beta2-adrenergic effects of the }(+) \text { isomer } \\
\text { counterbalance the vasoconstricting alpha-adrenergic effects, } \\
\text { often leading to little change or a reduction in systemic vascular } \\
\text { resistance }\end{array}$ & $\begin{array}{l}\text { - Hypotension, poor tissue perfusion (oliguria, anuria, altered } \\
\text { level of consciousness). } \\
\text { - Severely depressed left ventricular (LV) function with a low } \\
\text { cardiac index and elevated LV filling pressure, but in whom } \\
\text { extreme hypotension is not present (mean arterial BP }<70 \mathrm{~mm} \\
\text { Hg but no clinical shock). }\end{array}$ \\
\hline
\end{tabular}

Adapted from Peberdy et al. Circulation 2010 [28]

Table 8: Dosage of sympathomimetic agents.

Narrow-QRS-complex (SVT) tachycardias (QRS, 0.12 second)

- Sinus tachycardia

- Atrial fibrillation

- Atrial flutter

- AV nodal reentry

- Accessory pathway-mediated tachycardia

- Atrial tachycardia (including automatic and reentry forms)

- Multifocal atrial tachycardia (MAT)

- Junctional tachycardia (rare in adults)

- Ventricular tachycardia (VT) and ventricular fibrillation (VF)

- SVT with aberrancy

- Pre-excited tachycardias (Wolff-Parkinson-White[WPW] syndrome)

- Ventricular paced rhythms

Adapted from Neumar RW et al. Circulation 2010 [29]

Table 9: Classification of tachycardias.

ischemic chest discomfort, acute heart failure, hypotension, or other signs of shock, the patient should receive immediate treatment with pharmacotherapy and if required pacemaker implantation [29]. Atropine sulfate remains the first-line drug for acute symptomatic bradycardia. It reverses cholinergic-mediated decreases in heart rate and should be considered a temporizing measure while awaiting a transvenous pacemaker for patients with symptomatic sinus bradycardia, conduction block at the level of the $\mathrm{AV}$ node, or sinus arrest. The recommended atropine dose for bradycardia is $0.5 \mathrm{mg}$ IV every 3 to 5 minutes to a maximum total dose of $3 \mathrm{mg}$. Doses of atropine sulfate of $<0.5 \mathrm{mg}$ may paradoxically result in further slowing of the heart rate. Atropine administration should not delay implementation of pacing for patients with poor perfusion. Atropine should be used cautiously in the presence of acute coronary ischemia or MI; increased heart rate may worsen ischemia or increase infarction size. Atropine will likely be ineffective in patients who have undergone cardiac transplantation because the transplanted heart lacks vagal innervation. Although not first-line agents for treatment of symptomatic bradycardia, dopamine, epinephrine, and isoproterenol are alternatives when a bradyarrhythmia is unresponsive to or inappropriate for treatment with atropine, or as 


\begin{tabular}{|c|c|c|c|c|c|}
\hline Drug & Characteristics & Indication(s) & Dosing & Side Effects & $\begin{array}{l}\text { Precautions } \\
\text { or Special } \\
\text { Considerations }\end{array}$ \\
\hline Adenosine & $\begin{array}{l}\text { Endogenous purine } \\
\text { nucleoside; briefly } \\
\text { depresses sinus node rate } \\
\text { and AV node conduction; } \\
\text { vasodilator }\end{array}$ & $\begin{array}{l}\text { - Stable, narrow-complex } \\
\text { regular tachycardias } \\
\text { - Unstable narrow-complex } \\
\text { regular tachycardias before } \\
\text { electrical cardioversion } \\
\text { - Stable, regular, monomorphic, } \\
\text { wide complex tachycardia as } \\
\text { a therapeutic and diagnostic } \\
\text { maneuver }\end{array}$ & $\begin{array}{l}6 \mathrm{mg} \text { IV as a rapid IV push followed by } \\
\text { a } 20 \mathrm{~mL} \text { saline flush; repeat if required } \\
\text { as } 12 \mathrm{mg} \text { IV push }\end{array}$ & $\begin{array}{l}\text { Contraindicated in } \\
\text { patients with asthma; } \\
\text { may precipitate atrial } \\
\text { fibrillation, which may } \\
\text { be very rapid in patients } \\
\text { with WPW }\end{array}$ & $\begin{array}{l}\text { Hypotension, } \\
\text { bronchospasm, chest } \\
\text { discomfort. } \\
\text { Reduce dose in post- } \\
\text { cardiac transplant } \\
\text { patients, those taking } \\
\text { dipyridamole or } \\
\text { carbamazepine and } \\
\text { when administered via } \\
\text { a central vein }\end{array}$ \\
\hline $\begin{array}{l}\text { Diltiazem, } \\
\text { Verapamil }\end{array}$ & $\begin{array}{l}\text { Non-dihydropyridine } \\
\text { calcium channel } \\
\text { blockers; slow AV node } \\
\text { conduction and increase } \\
\text { AV node refractoriness; } \\
\text { vasodilators, negative } \\
\text { inotropes }\end{array}$ & $\begin{array}{l}\text { - Stable, narrow complex } \\
\text { tachycardias if rhythm remains } \\
\text { uncontrolled or unconverted by } \\
\text { adenosine or vagal maneuvers } \\
\text { or if SVT is recurrent } \\
\text { - Control ventricular rate in } \\
\text { patients with atrial fibrillation or } \\
\text { atrial flutter }\end{array}$ & $\begin{array}{l}\text { - Diltiazem: Initial dose } 15 \text { to } 20 \\
\mathrm{mg}(0.25 \mathrm{mg} / \mathrm{kg}) \text { IV over } 2 \text { minutes; } \\
\text { additional } 20 \text { to } 25 \mathrm{mg}(0.35 \mathrm{mg} / \mathrm{kg} \text { ) IV } \\
\text { in } 15 \text { minutes if needed; } 5 \text { to } 15 \mathrm{mg} / \mathrm{h} \\
\text { IV maintenance infusion (titrated to AF } \\
\text { heart rate if given for rate control) } \\
\text { - Verapamil: Initial dose } 2.5 \text { to } 5 \mathrm{mg} \text { IV } \\
\text { given over } 2 \text { minutes; may repeat as } 5 \\
\text { to } 10 \mathrm{mg} \text { every } 15 \text { to } 30 \text { minutes to total } \\
\text { dose of } 20 \text { to } 30 \mathrm{mg}\end{array}$ & $\begin{array}{l}\text { Hypotension, } \\
\text { bradycardia, } \\
\text { precipitation of heart } \\
\text { failure }\end{array}$ & $\begin{array}{l}\text { Should only be given } \\
\text { to patients with narrow- } \\
\text { complex tachycardias } \\
\text { (regular or irregular). } \\
\text { Avoid in patients with } \\
\text { heart failure and pre- } \\
\text { excited AF or flutter } \\
\text { or rhythms consistent } \\
\text { with VT }\end{array}$ \\
\hline $\begin{array}{l}\text { Atenolol, } \\
\text { Metoprolol, } \\
\text { Esmolol, } \\
\text { Propranolol }\end{array}$ & $\begin{array}{l}\text { b-Blockers; reduce } \\
\text { effects of circulating } \\
\text { catecholamines; reduce } \\
\text { heart rate, AV node } \\
\text { conduction and blood } \\
\text { pressure; negative } \\
\text { inotropes }\end{array}$ & $\begin{array}{l}\text { - Stable, narrow-complex } \\
\text { tachycardias if rhythm remains } \\
\text { uncontrolled or unconverted by } \\
\text { adenosine or vagal maneuvers } \\
\text { or if SVT is recurrent } \\
\text { - Control ventricular rate in } \\
\text { patients with atrial fibrillation or } \\
\text { atrial flutter } \\
\text { - Certain forms of polymorphic } \\
\text { VT (associated with acute } \\
\text { ischemia, familial LQTS, } \\
\text { catecholaminergic VT) }\end{array}$ & $\begin{array}{l}\text { - Atenolol (b1 specific blocker) } 5 \mathrm{mg} \\
\text { IV over } 5 \text { minutes; repeat } 5 \mathrm{mg} \text { in } 10 \\
\text { minutes if arrhythmia persists or recurs } \\
\text { - Metoprolol (b1 specific blocker) } 5 \\
\text { mg over } 1 \text { to } 2 \text { minutes repeated as } \\
\text { required every } 5 \text { minutes to maximum } \\
\text { dose of } 15 \mathrm{mg} \\
\text { - Esmolol (b1 specific blocker with } \\
\text { 2-to } 9 \text {-minute half-life) IV loading dose } \\
500 \text { mcg/kg ( } 0.5 \mathrm{mg} / \mathrm{kg} \text { ) over } 1 \mathrm{minute} \text {, } \\
\text { followed by an infusion of } 50 \mathrm{mcg} / \mathrm{kg} \\
\text { per minute ( } 0.05 \mathrm{mg} / \mathrm{kg} \text { per minute); if } \\
\text { response is inadequate, infuse second } \\
\text { loading bolus of } 0.5 \mathrm{mg} / \mathrm{kg} \text { over } 1 \\
\text { minute and increase maintenance } \\
\text { infusion to } 100 \mathrm{mcg} / \mathrm{kg}(0.1 \mathrm{mg} / \mathrm{kg} \text { ) } \\
\text { per minute; increment; increase in this } \\
\text { manner if required to } \\
\text { maximum infusion rate of } 300 \mathrm{mcg} / \mathrm{kg} \\
\text { @0.3 mg/kg\# per minute } \\
\text { - Propranolol (nonselective } \\
\text { b-blocker) } 0.5 \text { to } 1 \mathrm{mg} \text { over } 1 \mathrm{minute} \text {, } \\
\text { repeated up to a total dose of } 0.1 \mathrm{mg} / \\
\mathrm{kg} \text { if required }\end{array}$ & $\begin{array}{l}\text { Hypotension, } \\
\text { bradycardia, } \\
\text { precipitation of heart } \\
\text { failure }\end{array}$ & $\begin{array}{l}\text { Avoid in patients with } \\
\text { asthma, obstructive } \\
\text { airway disease, } \\
\text { decompensated heart } \\
\text { failure and pre-excited } \\
\text { artrial fibrillation or } \\
\text { flutter }\end{array}$ \\
\hline Procainamide & $\begin{array}{l}\text { Sodium and potassium } \\
\text { channel blocker }\end{array}$ & - Pre-excited atrial fibrillation & $\begin{array}{l}20 \text { to } 50 \mathrm{mg} / \mathrm{min} \text { until arrhythmia } \\
\text { suppressed, hypotension ensues, } \\
\text { or QRS prolonged by } 50 \% \text {, or total } \\
\text { cumulative dose of } 17 \mathrm{mg} / \mathrm{kg} \text {; or } 100 \\
\text { mg every } 5 \text { minutes until arrhythmia is } \\
\text { controlled }\end{array}$ & $\begin{array}{l}\text { Bradycardia, } \\
\text { hypotension, torsades } \\
\text { de pointes }\end{array}$ & $\begin{array}{l}\text { Avoid in patients with } \\
\text { QT prolongation and } \\
\text { CHF }\end{array}$ \\
\hline Amiodarone & $\begin{array}{l}\text { Multichannel blocker } \\
\text { (sodium, potassium, } \\
\text { calcium channel, and } \\
\text { noncompetitive a/b- } \\
\text { blocker) }\end{array}$ & $\begin{array}{l}\text { - Stable irregular narrow } \\
\text { complex tachycardia (atrial } \\
\text { fibrillation) } \\
\text { - Stable regular narrow- } \\
\text { complex tachycardia } \\
\text { - To control rapid ventricular } \\
\text { rate due to } \\
\text { accessory pathway conduction } \\
\text { in pre-excited atrial arrhythmias }\end{array}$ & $\begin{array}{l}150 \mathrm{mg} \text { given over } 10 \text { minutes and } \\
\text { repeated if necessary, followed by a } 1 \\
\mathrm{mg} / \mathrm{min} \text { infusion for } 6 \text { hours, followed } \\
\text { by } 0.5 \mathrm{mg} / \mathrm{min} \text {. Total dose over } 24 \\
\text { hours should not exceed } 2.2 \mathrm{~g} \text {. }\end{array}$ & $\begin{array}{l}\text { Bradycardia, } \\
\text { hypotension, phlebitis }\end{array}$ & \\
\hline Digoxin & $\begin{array}{l}\text { Cardiac glycoside } \\
\text { with positive inotropic } \\
\text { effects; slows AV node } \\
\text { conduction by enhancing } \\
\text { parasympathetic tone; } \\
\text { slow onset of action }\end{array}$ & $\begin{array}{l}\text { - Stable, narrow-complex } \\
\text { regular tachycardias if rhythm } \\
\text { remains uncontrolled or } \\
\text { unconverted by adenosine or } \\
\text { vagal maneuvers or if SVT is } \\
\text { recurrent } \\
\text { - Control ventricular rate in } \\
\text { patients with atrial fibrillation or } \\
\text { atrial flutter }\end{array}$ & $\begin{array}{l}8 \text { to } 12 \mathrm{mcg} / \mathrm{kg} \text { total loading } \\
\text { dose, half of which is administered } \\
\text { initially over } 5 \text { minutes, and remaining } \\
\text { portion as } 25 \% \text { fractions at } 4 \text {-to } 8 \text {-hour } \\
\text { intervals }\end{array}$ & Bradycardia & $\begin{array}{l}\text { Slow onset of action } \\
\text { and relative low } \\
\text { potency renders it less } \\
\text { useful for treatment of } \\
\text { acute arrhythmias }\end{array}$ \\
\hline
\end{tabular}

Adapted from Neumar R. W. Adult Advanced Cardiovascular Life Support 2010 American Heart Association Guidelines for Cardiopulmonary Resuscitation and Emergency Cardiovascular Care 


\begin{tabular}{|c|c|c|c|c|c|}
\hline Drug & Characteristics & Indication(s) & Dosing & Side Effects & $\begin{array}{l}\text { Precautions or Special } \\
\text { Considerations }\end{array}$ \\
\hline Procainamide & $\begin{array}{l}\text { Sodium and potassium } \\
\text { channel blocker }\end{array}$ & $\begin{array}{l}\text { - Hemodynamically stable } \\
\text { monomorphic VT }\end{array}$ & $\begin{array}{l}20 \text { to } 50 \mathrm{mg} / \mathrm{min} \text { until arrhythmia suppressed, } \\
\text { hypotension ensues, or QRS prolonged by } \\
50 \% \text {, or total cumulative dose of } 17 \mathrm{mg} / \mathrm{kg} \text {; or } \\
100 \mathrm{mg} \text { every } 5 \text { minutes until arrhythmia is } \\
\text { Controlled }\end{array}$ & $\begin{array}{l}\text { Bradycardia, } \\
\text { hypotension, } \\
\text { torsades de } \\
\text { pointes }\end{array}$ & $\begin{array}{l}\text { Avoid in patients with QT } \\
\text { prolongation and } \mathrm{CHF}\end{array}$ \\
\hline Amiodarone & $\begin{array}{l}\text { Multichannel blocker } \\
\text { (sodium, potassium, } \\
\text { calcium channel,and } \\
\text { noncompetitive a/b- } \\
\text { blocker) }\end{array}$ & $\begin{array}{l}\text { - Hemodynamically stable } \\
\text { monomorphic VT } \\
\text { - Polymorphic VT with } \\
\text { normal QT interval }\end{array}$ & $\begin{array}{l}150 \mathrm{mg} \text { given over } 10 \text { minutes and repeated if } \\
\text { necessary, followed by a } 1 \mathrm{mg} / \mathrm{min} \text { infusion for } \\
6 \text { hours, followed by } 0.5 \mathrm{mg} / \mathrm{min} \text {. Total dose } \\
\text { over } 24 \text { hours should not exceed } 2.2 \mathrm{~g} \text {. }\end{array}$ & $\begin{array}{l}\text { Bradycardia, } \\
\text { hypotension, } \\
\text { phlebitis }\end{array}$ & \\
\hline Sotalol & $\begin{array}{l}\text { Potassium channel } \\
\text { blocker and } \\
\text { nonselective b-blocker }\end{array}$ & $\begin{array}{l}\text { - Hemodynamically stable } \\
\text { monomorphic VT }\end{array}$ & $\begin{array}{l}\text { In clinical studies } 1.5 \mathrm{mg} / \mathrm{kg} \text { infused over } 5 \\
\text { minutes; however, any dose of the drug should } \\
\text { be infused slowly over a period of } 5 \text { hours }\end{array}$ & $\begin{array}{l}\text { Bradycardia, } \\
\text { hypotension, } \\
\text { torsades de } \\
\text { pointes }\end{array}$ & $\begin{array}{l}\text { Avoid in patients with QT } \\
\text { prolongation and } \mathrm{CHF}\end{array}$ \\
\hline Lidocaine & $\begin{array}{l}\text { Relatively weak sodium } \\
\text { channel blocker }\end{array}$ & $\begin{array}{l}\text { - Hemodynamically stable } \\
\text { monomorphic VT }\end{array}$ & $\begin{array}{l}\text { Initial dose range from } 1 \text { to } 1.5 \mathrm{mg} / \mathrm{kg} \mathrm{IV} \text {; } \\
\text { repeated if required at } 0.5 \text { to } 0.75 \mathrm{mg} / \mathrm{kg} \\
\text { IV every } 5 \text { to } 10 \text { minutes up to maximum } \\
\text { cumulative dose of } 3 \mathrm{mg} / \mathrm{kg} ; 1 \text { to } 4 \mathrm{mg} / \mathrm{min} \text { ( } 30 \\
\text { to } 50 \mathrm{mcg} / \mathrm{kg} \text { per minute) maintenance infusion }\end{array}$ & $\begin{array}{l}\text { Slurred } \\
\text { speech, altered } \\
\text { consciousness, } \\
\text { seizures, } \\
\text { bradycardia }\end{array}$ & \\
\hline Magnesium & $\begin{array}{l}\text { Cofactor in variety of } \\
\text { cell processes including } \\
\text { control of sodium and } \\
\text { potassium transport }\end{array}$ & $\begin{array}{l}\text { - Polymorphic VT associated } \\
\text { with QT prolongation } \\
\text { (torsades de pointes) }\end{array}$ & 1 to $2 \mathrm{~g} \mathrm{IV}$ over 15 minutes & $\begin{array}{l}\text { Hypotension, CNS } \\
\text { toxicity, respiratory } \\
\text { depression }\end{array}$ & $\begin{array}{l}\text { Follow magnesium levels } \\
\text { if frequent or prolonged } \\
\text { dosing required, particularly } \\
\text { in patients with impaired } \\
\text { renal function }\end{array}$ \\
\hline
\end{tabular}

Adapted from Neumar R. W. Adult Advanced Cardiovascular Life Support 2010 American Heart Association Guidelines for Cardiopulmonary Resuscitation and Emergency Cardiovascular Care

Table 11: Principal drugs used for ventricular tachycardia.

a temporizing measure while awaiting the availability of a pacemaker. Dopamine infusion may be used for patients with symptomatic bradycardia, particularly if associated with hypotension, in whom atropine may be inappropriate or after atropine fails (Class IIb, LoE B). Begin dopamine infusion at 2 to $10 \mathrm{mcg} / \mathrm{kg}$ per minute and titrate to patient response. Epinephrine infusion may be used for patients with symptomatic bradycardia, particularly if associated with hypotension, for which atropine may be inappropriate or after atropine fails (Class $\mathrm{IIb}, \mathrm{LoE} \mathrm{B}$ ). Begin the infusion at 2 to $10 \mathrm{mcg} / \mathrm{min}$ and titrate to patient response. Use of vasoconstrictors requires that the recipient be assessed for adequate intravascular volume and volume status supported as needed. Isoproterenol increases heart rate. The recommended adult dose is 2 to $10 \mathrm{mcg} / \mathrm{min}$ by IV infusion, titrated according to heart rate and rhythm response.

\section{Managements of Complications in Cath Lab}

Even if complications have fortunately become less common in the catheterization laboratory as cardiovascular procedures have matured, they still exist and required an immediate treatment. Apart the interventional treatment, pharmacotherapy remains essential in assisting complications in Cath Lab. For example during percutaneous access and coronary interventions some hemorrhagic complications (eg. retroperitoneal hematoma, coronary or cardiac chamber perforation) may occur, requiring an immediate reversal of anticoagulation. Protamine sulfate is a drug that reverses the anticoagulant effects of UFH by binding to it. Dosage for heparin reversal is 1.0 to $1.5 \mathrm{mg}$ protamine sulfate IV for every $100 \mathrm{IU}$ of UFH, not to exceed $50 \mathrm{mg}$. aPTT should be monitored at 5-15 minutes after dose then in 2-8 hours afterward [30]. However, it should be taken into account that protamine has been reported to cause allergic reactions that may manifest as urticaria, hypotension, pulmonary hypertension, bronchoconstriction, facial numbness, and cardiovascular collapse. Avoiding rapid infusion of protamine sulfate and pre-treating at-risk patients with histamine receptor antagonists ( $\mathrm{H} 1$ and $\mathrm{H} 2)$ and steroids may minimize these reactions.
Another complication that may occur during the cardiac catheterization procedures is represented by the systemic anaphylactoid reactions to iodinated contrast media. These reactions are non-immune mediated, but histamine release and other mediators produce a clinical presentation indistinguishable from anaphylaxis. Treatment strategies of anaphylactoid reactions to iodinated contrast media are reassumed in Figure 10. Five therapeutic agents are used for the treatment of anaphylactoid reactions: epinephrine, steroids, $\mathrm{H} 1$ blockers, $\mathrm{H} 2$ blockers, and volume administration [31]. In general, minor reactions such as limited urticaria may be watched for progression or treatment with diphenhydramine, whereas more serious reactions such as angioedema or laryngeal edema require airway stability and ephinephrine administration. Shock should be vigorously treated simultaneously with intravenous epinephrine and large volumes of normal saline. Epinephrine is the drug of choice for treating severe anaphylactoid reactions. It can be administered subcutaneously as $0.3 \mathrm{cc}$ of 1:1,000 dilution every $15 \mathrm{~min}$ up to a total dose of $1 \mathrm{cc}$. IV epinephrine provides rapid effect and avoids erratic, incomplete absorption from subcutaneous sites. An initial bolus of 10 $\mu \mathrm{g} / \mathrm{min}$ may be given safely and repeated until the desired initial result is obtained. This is followed by an infusion of $1-4 \mu \mathrm{g} / \mathrm{min}$ as clinically indicated. The bolus dose is prepared by diluting $0.1 \mathrm{cc}$ of $1: 1,000$ or $1 \mathrm{cc}$ of $1: 10,000$ solution in $10 \mathrm{cc} 0.9 \%$ normal saline $(10 \mu \mathrm{g} / \mathrm{cc})$ and the infusion by diluting $1 \mathrm{mg}$ ( $1 \mathrm{cc}$ of $1: 1,000$ or $10 \mathrm{cc}$ of $1: 10,000$ ) of epinephrine in $250 \mathrm{cc} 0.9 \%$ normal saline $(4 \mu \mathrm{g} / \mathrm{cc})$. High-dose IV steroids are frequently used in the treatment of anaphylactoid as they can potentially reduce the chance of delayed recurrent symptoms, which can be observed as long as $48 \mathrm{hrs}$ after the initial reaction. Diphenhydramine, an H1 histamine receptor blocker, is commonly administered in the treatment of anaphylactoid reactions in $25-50 \mathrm{mg}$ intravenous doses. $\mathrm{H} 2$ blocking agents should be considered in patients not responding to other measures. Finally, large volumes of fluid may be required for treatment of severe anaphylactoid reactions associated with hypotension. 


\begin{tabular}{|l|}
\hline \multicolumn{1}{|c|}{ Heparin } \\
\hline Initial standard in PCI \\
\hline $\begin{array}{l}\text { Initial dose of } 70-100 \text { units/kg (50-70 units/kg with GPIIb/IIIa } \\
\text { inhibitors) }\end{array}$ \\
\hline Shown to activate platelets \\
\hline Less predictable antithrombotic response \\
\hline Requires ACT monitoring \\
\hline
\end{tabular}

Figure 10: Antithrombins in primary PCI. ntiplatelet therapy in STEMI.

\section{References}

1. Seeliger E, Sendeski M, Rihal CS, Persson PB (2012) Contrast-induced kidney injury: mechanisms, risk factors, and prevention. Eur Heart J 33: 2007-2015.

2. Brar SS, Aharonian V, Mansukhani P, Moore N, Shen AY, et al. (2014) Haemodynamic-guided fluid administration for the prevention of contrastinduced acute kidney injury: the POSEIDON randomised controlled trial. Lancet 383:1814-1823.

3. Jang JS, Jin HY, Seo JS, Yang TH, Kim DK, et al. (2012) Sodium bicarbonate therapy for the prevention of contrast-induced acute kidney injury â€" a systematic review and meta-analysis â€“. Circ J 76: 2255-2265.

4. Greenberger PA, Patterson R, Radin RC (1984) Two pretreatment regimens for high-risk patients receiving radiographic contrast media. J Allergy Clin Immunol 74: 540-543.

5. Kern M (2009) Conscious Sedation in the Cath Lab: Should we use what GI uses? Cath Lab Digest 17:1.

6. Caputo RP, Tremmel JA, Rao S, Gilchrist IC, Pyne C, et al. (2011) Transradial arterial access for coronary and peripheral procedures: executive summary by the Transradial Committee of the SCAI. Catheter Cardiovasc Interv 78: 823-839.

7. Rathore S, Stables RH, Pauriah M, Hakeem A, Mills JD, et al.( 2010) Impact of length and hydrophilic coating of the introducer sheath on radial artery spasm during transradial coronary intervention: A randomized study. JACC Cardiovasc Interv 3:475-483.

8. Morey SS (1999) ACC and AHA update guidelines for coronary angiography. American College of Cardiology. American Heart Association. Am Fam Physician 60: 1017-1020.

9. Hung MJ, Hu P, Hung MY (2014) Coronary artery spasm: review and update. Int J Med Sci 11: 1161-1171.

10. Kern M (2012) Hypotension in the Cath Lab? Think Vagal Reaction Early. Cath Lab Digest 20: 2.

11. de Groote P, Lamblin N, Launay D, Bervar JF, Hachulla E (2010) Screening and diagnosis of pulmonary arterial hypertension. Comments regarding the latest guidelines from the European Societies of Cardiology and of Pulmonology. Presse Med. 39;1: 1S16-21.

12. Windecker S, Kolh P, Alfonso F, Collet JP, Cremer J, et al. (2014) 2014 ESC/ EACTS Guidelines on myocardial revascularization: The Task Force on Myocardial Revascularization of the European Society of Cardiology (ESC) and the European Association for Cardio-Thoracic Surgery (EACTS)Developed with the special contribution of the European Association of Percutaneous Cardiovascular Interventions (EAPCI). Eur Heart J. 1;35:2541-619.

13. Wessler JD, Stant J, Duru S, Rabbani L, Kirtane AJ (2015) Updates to the ACCF/AHA and ESC STEMI and NSTEMI guidelines: putting guidelines into clinical practice. Am J Cardiol 115: 23A-8A.

14. Wiviott SD, Braunwald E, McCabe $\mathrm{CH}$, et al. (2007) Prasugrel versus clopidogrel in patients with acute coronary syndromes. N Engl J Med 357: 2001-2015.

15. Wallentin L, Becker RC, Budaj A, Cannon CP, Emanuelsson H, et al. (2009) Ticagrelor versus clopidogrel in patients with acute coronary syndromes. $\mathrm{N}$ Engl J Med 361: 1045-1057.

16. Muñiz-Lozano A, Rollini F, Franchi F, Angiolillo DJ (2013) Update on platelet glycoprotein Ilb/llla inhibitors: recommendations for clinical practice. Ther Adv Cardiovasc Dis 7: 197-213.

17. Giugliano RP, White JA, Bode C, Armstrong PW, Montalescot G, et al.(2009) EARLY ACS Investigators. Early versus delayed, provisional eptifibatide in acute coronary syndromes. N Engl J Med 360: 2176-2190.

18. Stone GW, McLaurin BT, Cox DA, Bertrand ME, Lincoff AM, et al. (2006) Bivalirudin for patients with acute coronary syndromes. N Engl J Med 355 2203-2216.

19. O'Gara PT, Kushner FG, Ascheim DD, Casey DE Jr, Chung MK, et al. (2013) American College of Cardiology Foundation; American Heart Association Task Force on Practice Guidelines; American College of Emergency Physicians; Society for Cardiovascular Angiography and Interventions. 2013 ACCF/AHA guideline for the management of ST-elevation myocardial infarction: executive summary: a report of the American College of Cardiology Foundation/ American Heart Association Task Force on Practice Guidelines: developed in collaboration with the American College of Emergency Physicians and Society for Cardiovascular Angiography and Interventions. Catheter Cardiovasc Interv 82: E1-27.

20. Windecker S, Hernández-Antolín RA, Stefanini GG, Wijns W, Zamorano $\mathrm{JL}$ (2014) Management of ST-elevation myocardial infarction according to European and American guidelines. Eurolntervention 10 Suppl T: T23-31.

21. Stone GW, Maehara A, Witzenbichler B, Godlewski J, Parise H, et al. (2012) Intracoronary abciximab and aspiration thrombectomy in patients with large anterior myocardial infarction: the INFUSE-AMI randomized trial. JAMA 307: $1817-1826$.

22. Thiele H, Wo hrle J, Hambrecht R, Rittger H, Birkemeyer R, et al.( 2012) Intracoronary vs. intravenous bolus abciximab during primary percutaneous coronary intervention in patients with acute ST-elevation myocardial infarction: a randomised trial. Lancet 379: 923 -931.

23. Thiele H1, Ohman EM2, Desch S3, Eitel I3, de Waha S3 (2015) Management of cardiogenic shock. Eur Heart J 36: 1223-1230.

24. Hands ME, Rutherford JD, Muller JE, Davies G, Stone PH, et al.(1989) The in-hospital development of cardiogenic shock after myocardial infarction: incidence, predictors of occurrence, outcome and prognostic factors. The MILIS Study Group. J Am Coll Cardiol 14: 40-46.

25. Williams JF (1995) Guidelines for the evaluation and management of heart failure. Report of the American College of Cardiology/American Heart Association Task Force on Practice Guidelines (Committee on Evaluation and Management of Heart Failure).Circulation 92:2764-84.

26. Leier CV, Bambach D, Thompson MJ, Cattaneo SM, Goldberg RJ, et al. (1981) Central and regional hemodynamic effects of intravenous isosorbide dinitrate, nitroglycerin and nitroprusside in patients with congestive heart failure. Am J Cardiol 48: 1115-1123.

27. Opie LH, Gersh BJ (2012) Drugs for the Heart. (8thedn), Elsevier Health Sciences, China.

28. Peberdy MA, Callaway CW, Neumar RW, Geocadin RG, Zimmerman JL, et al.( 2010) Part 9: post-cardiac arrest care: 2010 American Heart Association Guidelines for Cardiopulmonary Resuscitation and Emergency Cardiovascular Care. Circulation 122: S768-86.

29. Neumar RW, Otto CW, Link MS, Kronick SL, Shuster M, et al.(2010) Part 8 adult advanced cardiovascular life support: 2010 American Heart Association Guidelines for Cardiopulmonary Resuscitation and Emergency Cardiovascular Care. Circulation. 122: S729-67.

30. Lemon SJ Jr, Crannage AJ (2011) Pharmacologic anticoagulation reversal in the emergency department. Adv Emerg Nurs J 33: 212-223.

31. Jerome E, Goss MD, Charles E, Chambers MD, Frederick A, et al. (2006) Members of the Laboratory Performance Standards Committee of the Society for Cardiac Angiography and Interventions. Systemic Anaphylactoid Reactions to lodinated Contrast Media During Cardiac Catheterization Procedures: Guidelines for prevention. Cath lab digest 14: 9. 